University of Nebraska - Lincoln

DigitalCommons@University of Nebraska - Lincoln

Faculty Publications from the Harold W. Manter Laboratory of Parasitology

$1-2007$

\title{
Multiplication of Ovaries in Ctenotaenia marmotae (Frölich, 1802) (Cestoda: Anoplocephalidae)
}

\author{
Sumiya Ganzorig \\ Hokkaido University, sganzorig@yahoo.com \\ Yuzaburo Oku \\ Hokkaido University, oku@vetmed.hokudai.ac.jp \\ Scott Lyell Gardner \\ University of Nebraska - Lincoln, slg@unl.edu \\ Masao Kamiya \\ Rakuno Gakuen University, mkamiya@rakuno.ac.jp
}

Follow this and additional works at: https://digitalcommons.unl.edu/parasitologyfacpubs

Part of the Parasitology Commons

\begin{abstract}
Ganzorig, Sumiya; Oku, Yuzaburo; Gardner, Scott Lyell; and Kamiya, Masao, "Multiplication of Ovaries in Ctenotaenia marmotae (Frölich, 1802) (Cestoda: Anoplocephalidae)" (2007). Faculty Publications from the Harold W. Manter Laboratory of Parasitology. 10.

https://digitalcommons.unl.edu/parasitologyfacpubs/10
\end{abstract}

This Article is brought to you for free and open access by the Parasitology, Harold W. Manter Laboratory of at DigitalCommons@University of Nebraska - Lincoln. It has been accepted for inclusion in Faculty Publications from the Harold W. Manter Laboratory of Parasitology by an authorized administrator of DigitalCommons@University of Nebraska - Lincoln. 
Comp. Parasitol.

74(1), 2007, pp. 151-153

\title{
Research Note
}

\section{Multiplication of Ovaries in Ctenotaenia marmotae (Frölich, 1802) (Cestoda: Anoplocephalidae)}

\author{
Sumiya Ganzorig, ${ }^{1,4}$ Yuzaburo OKu, ${ }^{1}$ Scott Lyell Gardner, ${ }^{2}$ and Masao Kamiya ${ }^{3}$ \\ ${ }^{1}$ Laboratory of Parasitology, Graduate School of Veterinary Medicine, Hokkaido University, \\ Sapporo 060-0818, Japan (e-mail: sganzorig@yahoo.com) \\ ${ }^{2}$ Harold W. Manter Laboratory of Parasitology, University of Nebraska-Lincoln, \\ W529 Nebraska Hall, Lincoln, Nebraska 68588-0514, U.S.A., and \\ ${ }^{3}$ Laboratory of Environmental Zoology, Department of Biosphere and Environmental Sciences, \\ Faculty of Environmental Systems, Rakuno Gakuen University, Bunkyodai-midorimachi 582, \\ Ebetsu, Hokkaido 069-8501, Japan
}

ABSTRACT: Individuals of the cestode species Ctenotaenia marmotae (Frölich, 1802) (Cestoda: Anoplocephalidae) possessing duplicated rudimentary ovaries toward the medial parts of the segments were found in material collected from the Siberian marmot (Marmota sibirica) in Mongolia. This tapeworm is characterized by possessing one pair of female genitals per segment. The extra rudimentary ovaries that we found ranged from 1 to 6 in number per segment and were much smaller than the main pairs of ovaries. Although multiplication of ovaries was reported to occur in a species of Diandrya (Darrah, 1930) by Rausch (1980), this is the first report of multiplication of ovaries in this species of cestode.

KEY WORDS: Cestoda, Anoplocephalidae, Ctenotaenia, marmotae, morphology, anatomy, marmot, Marmota sibirica, Sciuridae, rodent, Mongolia, Palearctic.

Ctenotaenia marmotae (Frölich, 1802) is a parasite of marmots and ground squirrels in Eurasia. In Mongolia it was first reported from the long-tailed ground squirrel, Spermophilus undulatus (Pallas, 1778) in Huvsgul Province (Ganzorig et al., 1988), and Danzan (1978) reported occurrences of Ctenotaenia citelli Kirshenblatt, 1933)—which Beveridge (1978) considered to be a synonym of C. marmotaein S. undulatus, Ochotona dauurica (Pallas, 1776), and Microtus oeconomus (Pallas, 1776) in Arhangai Province.

This cestode is characterized by having two sets of reproductive organs per segment, and although there have been many morphological studies of $C$. marmotae (see Spasskii, 1951; Spasskii and Shalayeva, 1961; Tenora, 1976; Beveridge, 1978; Tenora and Murai, 1978; Tenora, 1990; Tenora and Hörning, 1972; Tenora and Hönigova, 1990), Beveridge (1978) was the first to describe the presence of supernu-

\footnotetext{
${ }^{4}$ Corresponding author.
}

merary vitelline glands in mature segments. Here we report cestodes that we observed to possess extra rudimentary ovaries and compare our findings with what was previously reported for specimens of C. marmotae.

The material in this study was collected during a survey of helminths of rodents in Mongolia in 1996. The material was obtained from 2 of 3 Siberian marmots, Marmota sibirica (Radde, 1862), Sciuridae, captured in Mt. Ih Bogd uu lin Bayanhongor Province, Mongolia. Of the cestodes collected, 6 complete specimens were used in this study. In addition, 7 specimens of $C$. marmotae from the longtailed ground squirrel, Spermophilus undulatus Pallas, 1779 (Hanh County of Huvsgul Province), deposited at the Department of Zoology of the National University of Mongolia (Ulaanbaatar) were also examined. Cestodes were fixed in $70 \%$ alcohol, stained with aceto-carmine, dehydrated in ethanol, cleared in xylene, and mounted on slides under number 1 cover slips in Canada balsam. All measurements were made with the aid of an Olympus video micrometer (Model VM-30). The specimens were deposited in the Laboratory of Parasitology, Graduate School of Veterinary Medicine, Hokkaido University, Japan (Helm. Coll. No. 3000).

The specimens from the hosts, $M$. sibirica and S. undulatus, were morphologically identical, and their dimensions fit the ranges given by Beveridge (1978). Rudimentary ovaries were found in some mature and pregravid segments in all 6 specimens from $M$. sibirica, but not in those from $S$. undulatus. The extra ovarian tissue is present near the posterior margin of the segment, between the fully developed ovary and the midline, posterior to the uniformly arranged linear testes and closely associated with additional vitelline glands (Figs. 1-3) (see Beveridge, 1978). In our specimens, the number of rudimentary 


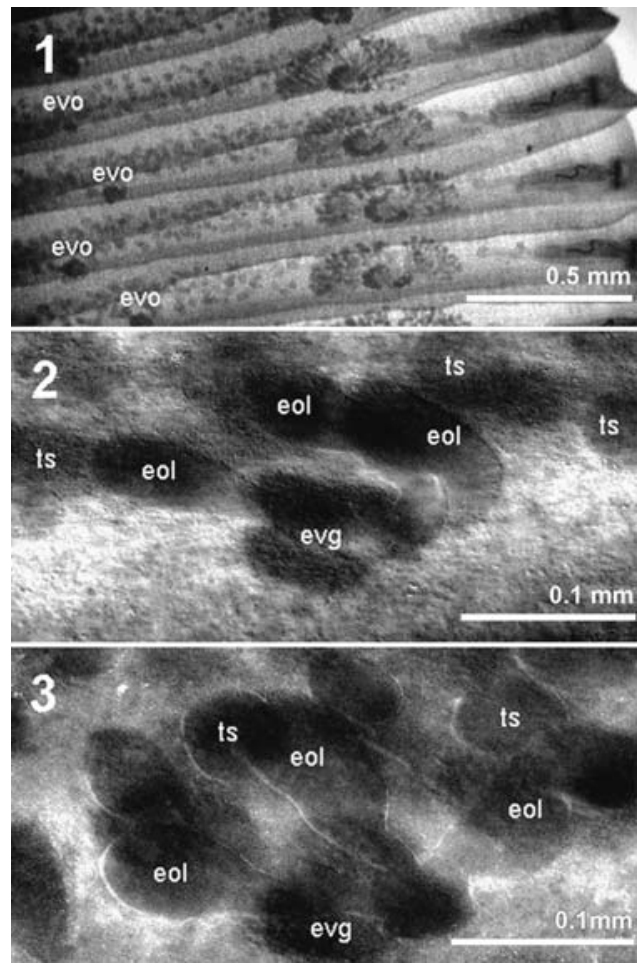

Figures 1-3. Ctenotaenia marmotae from Marmota sibirica. 1. Placement of organs in mature segments, ventral view. 2, 3. Details of rudimentary ovary, ventral view. (evo, extra vitelline gland and ovary; eol, extra ovary lobule; evg, extra vitelline gland; ts, testes).

ovaries ranged from 1 to 6 (mean, 4.1) per segment, and they were much smaller than the main ovary. Rudimentary ovaries possessed from 1 to 7 lobules (mean, 5), whereas the main ovary consisted of 44 to 86 lobules (mean, 62.6). One to 9 (mean, 3.1) additional vitelline glands of various shapes and sizes were present in all specimens from both host species and were located posterior to the testes in most premature, mature, and pregravid segments. The rudimentary ovaries measured $0.079-0.133 \mathrm{~mm}$ by $0.063-0.132 \mathrm{~mm}$, about half the size of the fully developed ovaries $(0.191-0.282 \mathrm{~mm}$ by $0.099-0.169$ $\mathrm{mm})$. Posteriad, the rudimentary ovaries persisted in the developing and maturing segments much longer than normal ovarian tissues, vitelline glands, and testes and were present in segments already filled by the developing uterus. In the present study, rudimentary ovaries were not found in specimens from $S$. undulatus, although sections were made and examined carefully.

The results are of special interest with respect to the evolution of the uterus in this family of cestodes, with variation ranging from very simple to highly differentiated and complex. The presence of additional ovaries has not been reported in any previous descriptions of this species; however, a similar structure was described by Rausch (1980) in Diandrya composita Darrah, 1930 from Nearctic marmots. He found that rudiments of the supernumerary female genital organs were taken to be "interproglottidal glands" reported in earlier descriptions of this species. The rudimentary female genital organs we found in C. marmotae show close similarity in location, comparative size, and number with those present in $D$. composita. In both species of parasites, the rudimentary organs persist longer than normal organs.

Cestodes with paired genitalia are present in nearly half of all genera of the family Anoplocephalidae. Beveridge (1978) suggested that duplication of genitalia occurs invariably within the same host group and is clearly a common phenomenon within this family. The duplication of genitalia in these cestodes is suggested to be apomorphic, whereas single genitalia are considered a primitive or plesiomorphic state (Beveridge, 1994). The multiplication of female genital organs in both Ctenotaenia and Diandrya and the historical geography of the host group support this hypotheses. The genus Diandrya was suggested by Rausch (1980) to be a derivative of Andrya and perhaps arose in Nearctic marmots during the early Pleistocene, after the trans-Beringian dispersal of Marmota to the Palearctic (Rausch, 1980).

Interestingly, marmots in the Holarctic region serve as hosts for species of Paranaplocephala, whereas the origination of species of Ctenotaenia in marmots in the Palearctic region seems to parallel the simultaneous but vicariant origin of species of Diandrya in marmots of the Nearctic region. This curious geographic vicariance seems worthy of additional study, and perhaps some light can be shed on this by work now being conducted by the field teams of the Beringian Coevolution Project in both the Nearctic and the Palearctic regions.

\section{LITERATURE CITED}

Beveridge, I. 1978. A taxonomic revision of the genera Cittotaenia Riehm. 1881, Ctenotaenia Railliet, 1893, Mosgovoyia Spasskii, 1951 and Pseudocittotaenia Tenora, 1976 (Cestoda: Anoplocephalidae). Mémoires du Muséum National d'Histoire Naturelle 107:1-64.

Beveridge, I. 1994. Family Anoplocephalidae Cholodkovsky, 1902. Pages 315-366 in L. F. Khalil, A. Jones, and R. A. Bray, eds. Keys to the Cestode Parasites of Vertebrates. CAB International, Wallingford, Oxon, U.K.

Danzan, G. 1978. [On the fauna of Acanthocephala and Cestoda in lagomorphs and rodents in the Mongolian 
People's Republic.] Pages 169-176 in Epidemiologiya I profilaktika osobo opasnyh infektsii v MNR i SSSR. Ulaanbaatar, Mongolia. (In Russian.)

Ganzorig, S., G. Danzan, J. Burmaa, and B. Enhtuya. 1988. [New findings of helminths from mammals in Huvsgul area.] Pages 120-121 in Natural Conditions and Resources of the Some Regions of Mongolia. Irkutsk State University, Irkutsk, USSR. (In Russian.)

Rausch, R. L. 1980. Redescription of Diandrya composita Darrah, 1930 (Cestoda: Anoplocephalidae) from nearctic marmots (Rodentia: Sciuridae) and the relationships of the genus Diandrya emend. Proceedings of the Helminthological Society of Washington 47: 157-164.

Spasskii, A. A. 1951. Essential of Cestodology. Vol. 1. Izdatelstvo Academii Nauk SSSR, Moscow, USSR. 730 pp. (In Russian.)

Spasskii, A. A., and N. M. Shalayeva. 1961. [The findings of Ctenotaenia marmotae (Frölich, 1802) in Marmota in USSR.] Trudy GELAN 11:286-292. (In Russian.)
Tenora, F. 1976. Tapeworms of the family Anoplocephalidae Cholodkowsky, 1902-evolution implication. Acta Scientarum Naturalium Academiae Scientiarum Bohemoslovacae 5:1-37.

Tenora, F. 1990. Anatomy of C. marmotae (Frölich, 1802) (Cestoda: Anoplocephalidae). Acta Universitatis Agriculturae, Facultas Agronomica, Brno 38:217-220.

Tenora, F., and M. Hönigova. 1990. An addition to the morphology of Ctenotaenia marmotae (Frölich, 1802) (Cestoda: Anoplocephalidae). Helminthologia 27: 163-172.

Tenora, F., and B. Hörning. 1972. Tapeworms of the genus Ctenotaenia Raillet, 1893 (Cestoidea)-parasites of mammals of the genus Marmota (Rodentia). Acta Universitatis Agriculturae, Facultas Agronomica, Brno 20:139-146.

Tenora, F., and E. Murai. 1978. Anoplocephalidae (Cestoda)_parasites of Leporidae and Sciuridae in Europe. Acta Zoologica Academiae Scientiarum Hungaricae 3-4:415-429. 